\title{
Capital Structure Policy And Effect On Return Investments In Automotive Stock Exchange
}

\author{
Edisah Putra Nainggolan' ${ }^{1}$, Hade Chandra ${ }^{2}$ Batubara and Dodi Firman ${ }^{3}$ \\ \{edisahputra@umsu.ac.id ${ }^{1}$ \} \\ ${ }^{1,2,3}$ University of Muhammadiyah Sumatera Utara, Jl. Kapten MuchtarBasri No. 3 Medan, \\ Indonesia
}

\begin{abstract}
This study aims to determine the effect of capital structure policy and its effect on the rate of return on investment.The population used in this study is a company engaged in the Automotive business group and components on the stock exchange from 2010-2015, totaling 13 Automotive companies and components. While the data analysis technique uses multiple linear regression.Based onThe research obtained results in part that the capital structure policy did not significantly affect the rate of return on investment in the Automotive and Component business groups on the Stock Exchange.
\end{abstract}

Keyword: Policy Capital Structure, Rate of return on capital

\section{Introduction}

In operating a business, of course maximum profit becomes an orientation for the company to be able to survive and be able to develop well. "Profitability is the company's ability to seek profits. Profitability is a factor that should get special attention because to be able to live a company, the company must be in a favorable condition. Without profit, it will be difficult for a company to attract capital from outside. Profitability is often used to measure the efficiency of the use of capital in a company by comparing the capital achieved with operating profit"(Kasmir, 2014).

To measure profitability there are several indicators, namely"NetProfit Margin, Gross Profit Margin, Return On Investment(ROI), Return On Equity (ROE), Return On Assets (ROA) and Earning Per Share. But in this study the measurement of profitability is only limited to the use of Return On Equity (ROE)"(Harmono, 2011). "Return On Equity (ROE) is the company's ability to generate its own capital gains. This ratio is the ratio of net income available to the owner of the company with the amount of equity, so that this variable besides showing the rate of return of the owner, is also a measure of the efficiency of capital use"(Sutrisno, 2010). Whereas "Return On Equity (ROE) is used to measure the Rate of Return of equity. Securities analysts and shareholders generally pay close attention to this ratio. The higher the return generated by a company, the higher the price will be"(Tambun, 2012)

The Automotive sector and components are important sectors in the Indonesian economy, because, this industry is a superior export product and also a type of industry that absorbs labor in bulk. In addition, this sector is also supported by the existence of potential natural resources, and is easy to find in large numbers of workers. Therefore this sector is the biggest contributor to state income from groups outside of oil and gas.

The company's profitability is influenced by various factors, namely the shape, size and length of the company standing, as well as the capital structure, as well as what 
is the product produced. Capital structure becomes important for the company, because it will have an influence on the company's financial condition. If a company has a poor capital structure condition with a lot of debt conditions, this will certainly be an obstacle to the survival of the company. "Capital structure is permanent expenditure which reflects the balance between long-term debt and own capital" (Riyanto, 2008).

"The capital structure is basically related to the source of funds that come from internal and external companies. Internal funds can be either retained earnings and depreciation while the funds obtained from external sources are the funds derived from the creditors, holders of debt securities(bondholders)and owner of the company"(Joni dan Lina, 2010)

"The selection of financing is a critical issue for firms, especially the long-term financing in which leads to firm's future investment opportunity. Choice of long-term financing mix employed by the firm are called capital structure, composing financing from debt, equity and hybrid securities that a firm uses to generate its assets, operations and future growth. Capital structure decisions therefore are one of the most important issues in financial management in which can contribute to maximize the firm's value"(Thippayana, 2014).

"The optimal capital structure evolves persistently, and successful corporate leaders must constantly consider factors such as the company and its management, the economy, government regulation and social trends, the state of capital markets, and industry dynamics" (Handoo and Sharma, 2014)

"Optimizing the debt structure has an impact on capital structure decisions, and leads to increases in leverage ratios compared to a pure fixed-rate debt program. for realistic parameter values, jointly optimizing the debt and capital structures generates a significant increase in firm value with respect to a situation where only the capital structure is optimized" (Martellini, L., Milhau, V. \&Tarelli, 2013).

Origin of funds obtained from the owner of the company referred to as the capital alone, on the contrary, those sourced from outside parties are for the company. "Decisions regarding the use of debt or equity in financing are fully held by the financial manager. This is to determine the value and minimize the large risks associated with the use of debt"(Liem, 2013). Therefore, financial managers must pay attention to the cost of capital must also determine whether the needed funding needs must be obtained with their own capital or filled with capital from outside.

"Indicators commonly used to determine the composition of the capital structure areDebt to Assets, Long Term Debt to Equity and Debt to Equity. In this study the measurement of profitability is only limited to the use of Debt to Equity and Long Term Debt to Equity"(Harmono, 2011).

"The debt to capital ratio is a ratio of the ratios used to assess debt with equity. This ratio is sought by comparing all debt, including current debt with all equity. This ratio is useful to know the amount of funds provided by the borrower (creditor) with the owner of the company. In other words, this ratio serves to know every rupiah of its own capital which is used as collateral for debt"(Kasmir, 2014).

"DER can be used to see the capital structure of a company because high DER indicates that the capital structure of the business uses more debt relative to equity. The higher DER reflect risk companies is relatively high because of the company in operation is relatively dependent on the debt and the company has an obligation to pay interest on the debt as a result of investors tend to avoid stocks - stocks that have the value of DER high"(Kasmir, 2014) 
"The ratio of term debt length is a ratio measured by the comparison between long-term debt and equity. The aim is to measure what part of equity (own capital) is used as collateral for long-term debt. The greater this ratio shows the greater the interest expense and long-term debt that must be paid so that it will reduce the company's profits" (Kasmir, 2014)

\section{Literature Review}

\subsection{Return On Equity (ROE)}

Profitability is a part of measuring company performance that can reflect the way a company earns profits by using existing resources in the company, among others, through operational activities. Profitability will be a measure of overall management effectiveness based on the amount of profit obtained from the returns on working capital, sales, and investments that use percentages as a measure.

This ratio is a measure of shareholder profitability. One of the reasons for the company in its operations to get the maximum profit possible for shareholders. The following is the definition of Return On Equity (ROE) according to experts including:

"Something that is obtained from return on capital (ROE) or capital profitability is a way to measure net income after tax with own capital. This high ratio will show good performance. It means the owner's position is getting stronger, and vice versa"(Kasmir, 2014). "Return On Equity (ROE) is to show the ability of equity (generally ordinary shares) owned by the company to generate profits."(Hani, 2014)

\subsection{Debt to capital ratio (DER)}

In describing the condition of a company financed by debt, it can be seen through the debt ratio versus capital (DER). Comparison of debt with capital (DER) describes the percentage between total debt and total capital. Total debt is total liabilities (longterm and short-term debt), while totalcapitalis the total self-owned capital (shares and retained earnings) in the company.

(Brigham dan Houston, 2011)states"The ratio of debt to equityis used to assess the debt by equity, this ratio is useful to know the amount of funds provided borrowers (creditor) with the owner of the company". For companies the greater the ratio, the better, on the contrary with a low ratio, the higher the level of funding provided by the owner and the greater the security limit for the borrower in the event of loss or depreciation of the asset value, the higher the ratio Leverage represented by the ratio of debt to capital, the greater the company's profit, this is because the company has a large working capital and is accompanied by the company's ability to manage large working capital effectively, resulting in large profits, If the profits obtained by large companies, the Price Earning Ratio will also received by investors more and more "

\subsection{Long term Debt to capital ratio (LDER)}

Ratioobligationlong term (LDER) is a ratio that measures between long-term liabilities compared to existing capital in the company. Then it is used as a measure of how much part of equity (equity) that guarantees long-term debt. The smaller ratio obtained will show good conditions for the company to fulfill its long-term obligations. The amount of debt contained in the capital structure of the company must be understood regarding the balance between risk and profits obtained. Debt has 
implications for the risk caused, debt will have an impact on the existence of a fixed bond for the company to pay obligations to pay both the principal and interest periodically. The long-term debt ratio (LDER) also reflects the percentage of funds held by shareholders on their long-term obligations. According to(Kasmir, 2014) "Long Term The ratio of debt to capital is the ratio between long-term debt with own capital. The aim is to measure how much of each rupiah is used as collateral for long-term debt by comparing the long-term debt with the capital provided by the company "

Whereas according to(Sawir, 2012) that"Long Term The ratio of debt to capital is a comparison between long-term debt to company capital (shareholders)".

The theoretical framework of this research is presented in the following figure:

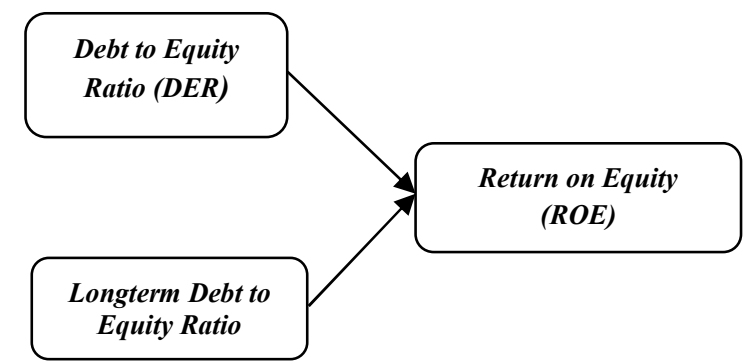

Fig.1. Theoretical Framework

\section{Research Methods}

In this research the researcher used an associative approach. Associative research (associative research) is a statement of researchers who are testing the relevance of the variable variables to be studied. The population is the group of the Automotive industry and Component years 2010-2015, which has a population of 13 companies and a sample of 10 companies. This research uses secondary types of data from publications on the stock exchange website. The data collection technique used is documentation, which is through collecting several documents obtained from the company including financial reports and other reports that are useful for the completion of this research. The data analysis technique used is multiple linear regression.

\section{Research Results}

\subsection{Multiple linear regression Multiple}

linear regression can be used to test the relationship between independent variables on the dependent variable using the regression equation $Y=a+b_{1} X_{1}+b_{2} X_{2}+$ $\varepsilon$. The value of $\mathrm{a}=1.413$ with the direction of a positive relationship indicates that if all the independent variables in the condition of eating will be zero, then the dependent variable is 1.413 . The value of $X_{1}$ is 0.337 with the direction of a positive relationship indicating that if the debt to capital ratio (DER) increases, the ROE will increase by 0.337 or $33.7 \%$ assuming other variables are constant. The value of $X_{2}$ of -0.203 with the direction of the negative relationship indicates that if LongtermThe debt to capital ratio (LDER) has increased, resulting in a decrease in Return on Equity (ROE) of 0.203 or $20.3 \%$, and vice versa if Longterm The debt to capital ratio (LDER) has decreased, 
resulting in an increase in Return on Equity (ROE) of 0.203 or $20.3 \%$ assuming other variables are constant.

\subsection{Hypothesis Testing}

Table 1. Regression

\begin{tabular}{llllll}
\hline $\begin{array}{c}\text { Hypothe } \\
\text { sis }\end{array}$ & VariableModel & SE & P & Results \\
\hline H1 & DER & RO & 1075 & 0287 & $\begin{array}{l}\text { Not } \\
\text { E }\end{array}$ \\
\hline H2 & LTDE & RO & -1 & 0,316 & Not \\
& R & E & 012 & & Supported \\
\hline
\end{tabular}

Note: DER $=$ Debt Equity Ratio, LTDER = Long term Debt to Equity Ratio, $R O E=$ Return on Equity

To determine the influence between variables it is determined that a significant value must be less than 0.05 (p 5 0.05). Based on the results of the partial test the effect of the debt to capital ratio on the Return on Equity obtained has a significant number of $0.287>0.05$. this means that $\mathrm{H}_{0}$ is accepted $\left(\mathrm{H}_{\mathrm{a}}\right.$ rejected $)$, this shows that there is no significant effect between the debt to capital ratio on Return On Equity in the Automotive and Component companies listed on the IDX.

Based on the results of testing partially the effect of the Long term debt to capital ratio (LDER) to Return On Equity (ROE)obtained a significant number of $0.316>0.05$ means that $\mathrm{H}_{0}$ is accepted $\left(\mathrm{H}_{\mathrm{a}}\right.$ rejected), meaning there is no significant effect between the Long term debt to capital ratio (LDER) to Return on Equity (ROE)the Automotive and Component companies listed on the IDX.

\section{Discussion}

\subsection{The Effect of Debt to Capital Ratio (DER) on Return On Equity (ROE)}

The results of this study do not support the debt ratio theory which states that if the debt to capital ratio rises then the Return On Equity value also increases. According to(Hani, 2014) "The ratio of debt to capital shows how much part of each of its own capital is used as collateral for the overall debt. The higher this ratio means the higher the amount of outside funds that must be guaranteed by the amount of own capital". Research contradicts the results obtained by the study (Salim, 2015) in his journal revealing that: "DER has a positive and significant effect on ROE". Based on the results of the research conducted by the author, as well as the opinions, theories and previous research above regarding the effect of the debt to capital ratio (DER) onReturn on Equity (ROE), this is because the years used in research are less than optimal, the companies studied differ, hypotheses not supported by empirical data and several other factors, the authors can conclude that there is no significant effect on the debt to capital ratio (DER) to Return on Equity (ROE) in Automotive and Component companies listed on the Indonesia Stock Exchange 2010-2015. This means that the increase in the debt to capital ratio (DER) will result in a decrease in Return on Equity(ROE) and vice versa.

\subsection{Influence of Long term Debt to capital ratio (LtDER) to Return On}


This study received the results of the research conducted (Phan Thi Bich Nguyet and, 2017), 2017) "concluding partially the results of the study showed that the LDR was notaffect Return on Equity". Based on the results of research conducted by the author, as well as opinions, theories and previous research above regarding the effect of $L D E R$ on ROE, this is because the years used in research are less than optimal, the companies studied differ, hypotheses are not supported by empirical data and several other factors. The author can conclude that there is no significant effect on $L D E R$ ) on $R O E$ in Automotive and Component companies listed on the Indonesia Stock Exchange for the period 2010-2014. This means that the increase and decrease in $L D E R$ do not have a direct impact on $R O E$.

\section{Conclusion}

From the above discussion it can be concluded, there is no significant effect of DER on (ROE) in the Automotive and Component business groups listed on the Stock Exchange. This indicates that the increase or DER will not result in an increase or decrease in ROE. There is no significant effect of $L D E R$ on ROE on Automotive and Component companies listed on the Stock Exchange. This shows that increasing LDER will not result in an increase or decrease in ROE.

\section{References}

[1] Brigham dan Houston (2011) Fundamentals of Financial Management. Jakarta: Salemba Empat.

[2] Handoo, A. and Sharma, K. (2014) 'A study on determinants of capital structure in India', IIMB Management Review. Elsevier Ltd, 26(3), pp. 170-182. doi: 10.1016/j.iimb.2014.07.009.

[3] Hani, S. (2014) Financial Statement Analysis Techniques. first one. Medan: In Media.

[4] Harmono (2011) Financial Management Based on the Balanced Scorecard Theory, Case and Business Research Approaches. Jakarta: Bumi Aksara.

[5] Joni dan Lina (2010) 'Factors Affecting Capital Structure', Business and Accounting, 2(12), pp. 81-96.

[6] Kasmir (2014) Introduction to Financial Management. Jakarta: Kencana Prenada Media Group.

[7] Liem (2013) "Analysis factorstors affecting capital structure on Industry Consumer Goods listed on the Stock Exchange the period 2007-2011', Journal of Student Scientific University of Surabaya, 2(1), pp. 115-120.

[8] Martellini, L., Milhau, V. \&Tarelli, A. (2013) 'Capital structure decisions and the optimal design of corporate market debt programs.', Journal of Corporate Finance, 49, pp. 141-167.

[9] Phan Thi Bich Nguyet and, L. T. P. V. (2017) 'Capital structure and firm performance: Empirical evidence from a small transition country', Research in International Business and Finance, 42, pp. 710-726.

[10] Riyanto, B. (2008) Basics of Corporate Spending. Yogyakarta: BPFE.

[11] Salim, J. (2015) 'Pengaruh Leverage (Dar, Der, Dan Tier) Terhadap Roe Perusahaan Properti Dan Real Estate Yang Terdaftar Di Bursa Efek Indonesia Tahun 2010 - 2014', Fakultas Ekonomi dan Bisins Perbanas Institute, 1(1).

[12] Sawir, A. (2012) Analysis of Financial Performance and Corporate Financial 
Planning. Fifth. Jakarta.

[13] Sutrisno (2010) Financial Management Concept Theory and Application. Yogyakarta: Ekonosia.

[15] Tambun (2012) Assessing Fair Prices of Shares. Jakarta: Gramedia Pustaka Utama.

[16] Thippayana, P. (2014) 'Determinants of Capital Structure in Thailand', Procedia - Social and Behavioral Sciences. Elsevier B.V., 143, pp. 1074-1077. doi: 10.1016/j.sbspro.2014.07.558. 